\title{
多孔質材構成式の延性破壊解析への適用*
}

\author{
吳 屋 守 章*1, Robert. SOWERBY*2 \\ 宮 城 清 宏*1, 系 村 昌 祐*1
}

\section{A Constitutive Law for Porous Material and Its Application to Ductile Fracture Analysis}

\author{
Moriaki GOYA, Robert SOWERBY, \\ Kiyohiro MIYAGI and Shosuke ITOMURA
}

\begin{abstract}
A model for the onset of ductile fracture in porous media is proposed and applied to the onset of void coalescence in the neck of a tensile specimen. A constitutive law for a rigid-work hardening porous solid is developed, based on an anisotropic yield function introduced by the authors in a previous report. The constitutive law embodies the void evolution model suggested by Rice and Tracey ${ }^{(6)}$. The onset of void coalescence is based on a criterion of internal necking of the matrix ligaments between the voids. This model was developed by Thomason ${ }^{(1)}$ for the plane strain case. The model is extended in the present study to include axial symmetry, and then it is shown that the extended model coincides qualitatively well with the fracture strain variation obtained experimentally by Edelson and Baldwin ${ }^{(4)}$ for sintered porous materials.
\end{abstract}

Key Words : Ductile Fracture, Porous Material, Constitutive Law, Plasticity, Anisotropy

\section{1. 緒言}

延性材料の破壊が空孔の発生・成長・合体と言う三 つの過程を経た最終的段階であり,そこでは一種の多 孔質材的様相を帯びていることは広く知られている。 そして, 破断直前においてくびれ部の中央部では引張 りの高静水圧状態が発生するので, 空孔成長に対する 静水圧成分の影響の取扱いは延性破壊メカ二ズムの解 析における重要な問題であると思われる。

延性破壊に関する微視的観点, すなわち着目する構 造のレベルとして空孔や空孔間のリガメント部の力学 的・幾何学的条件に着目する観点からの理論としては,

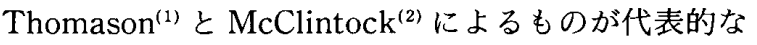
ものとしてあげられる. Thomason は, 多孔質材の平 面ひずみ変形を前提として理論を展開し, 空孔の成長 に関連して，そのアスペクト比は多孔質体全体の巨視 的ひずみ履歴に応じて変化するが, 空孔率自体は変形 中も一定で推移するとしている.しかしながら，上述 のように空孔率が静水圧成分に著しく依存するもの

\footnotetext{
* 平成 5 年 11 月 16 日 材料力学部門講演会において講演, 原 稿受付 平成 6 年 1 月 10 日.

*1 正員, 琉球大学工学部 ( $8903-01$ 沖繩県中頭郡西原町千原 1 番地).

*2 McMaster 大学工学部 (Hamilton, Ontario, CANADA).
}

であることを多くの実験や理論が既に示しているこ とを考えれば，この理論での空孔率一定という仮定は 一つの改善されるべき点とみなされよう。また， McClintock は Bergによる二次元的粘性変形場解 析 ${ }^{(3)}$ を拡張し,だ円柱状空孔の成長に対するひずみ履 歴の影響を調べ, 静水圧成分の効果が重大なることを 明らかにしている。

これら二つの理論は，空孔の合体条件に対しても異 なった規準を与えている. Thomasonにより提案され たものは, 空孔間のりガメント部への変形集中開始点 を合体条件とし，力学的観点より定められている. 他 方, McClintockにより与えられたものは，2 個の隣 接する空孔が互いに接触するという純幾何学的条件と して定められている。そして，これら二つの理論を焼 結材に対する Edelsonと Baldwinによる実験結果(4) と比較するとき, Thomasonの理論のほうがよく一致 する傾向を示すことが周知のこととなっている.

ところで, Goya, Nagaki および Sowerbyは多孔 質材の空孔のアスペクト比が変わることによって異方 性が引き起こされ得ると仮定し, 異方性多孔質材に対 する降伏関数についての検討を行ってきた ${ }^{(5)}$.

本報においては，こうした多孔質材異方性構成式の 適用性を示すため, Thomason の理論の改善を念頭に 
置き，一軸引張下の多孔質丸棒の延性破壊解析を試み ることを目的とする。なお，多孔質材に対する構成式 の誘導を完結するためには空孔の成長に関する発展式 が必要となるが,これについては空孔と母材のひずみ 場に対するRice とTraceyの研究(6) において用いら れた仮定を導入し発展式を得た。また，くびれ部の静 水圧応力を Bridgman の近似式(7)により評価し, 塑性 理論の上界法を軸対称単位セル問題に適用し, Thomasonの平面ひずみ場に対するアプローチと同 様に『拘束係数』を求めることにより臨界条件を提案 した.

\section{2. 直交異方性多孔質材に対する構成式}

丸棒くびれ部の中心部において直交異方性状態，す なわち応力とだ円空孔の主軸が一致するとし，ただし， 初期において空孔は球状で一様に分布しており，した がって, 空孔の初期分布については等方的であると仮 定する。よって，構成式を得るために導入された下記 の降伏関数式 (1)における空孔の分布モデルに関わる 補正係数 $q_{1}$ と $q_{2}$ は，等方性に近い正四面体モデル(3) に基づいて值が決定された。すなわち，等方性条件を 課した降伏関数式（1）が正四面体モデルに対する純粋 静水压応力および純粋相当応力の二つの特別な場合の 降伏条件を満足するように決定した $q_{1}=1.283$ また $q_{2}$ $=0.788$ を用いることにする。

$$
\begin{aligned}
& F(\sigma, Y, f)=\left(S_{\mathrm{eq}} / Y\right)^{2} \\
& \quad+q_{1} f R_{O} \cdot E_{X}-1=0
\end{aligned}
$$
ただし，

$$
\begin{aligned}
& S_{\mathrm{eq}}^{2} \equiv(3 / 2) S_{i}^{\prime} S_{i}^{\prime} \cdots \cdots \cdots \\
& \boldsymbol{S} \equiv(1 / 2)(\boldsymbol{\Phi} \boldsymbol{\sigma}+\boldsymbol{\sigma} \boldsymbol{\Phi})
\end{aligned}
$$

$$
\boldsymbol{\sigma} \equiv\left[\begin{array}{ccc}
\sigma_{1} & 0 & 0 \\
0 & \sigma_{2} & 0 \\
0 & 0 & \sigma_{3}
\end{array}\right] .
$$

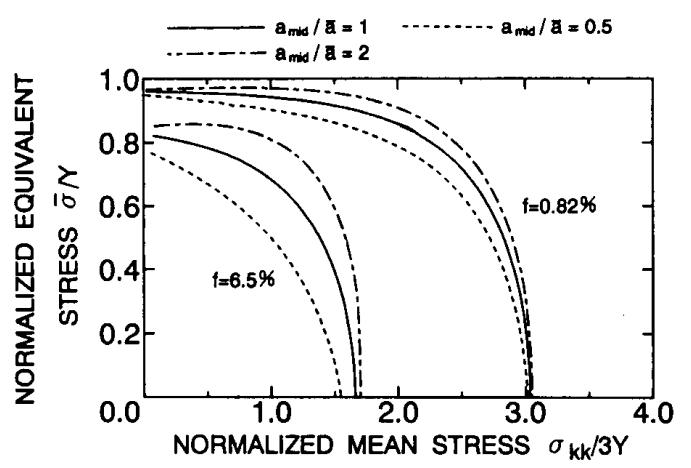

図 1 半径比 $a_{3} / a_{\mathrm{m} \text { Id }}=0.5,1$ および 2 のだ円体空孔に対す 万異方性降伏関数式 (1) の)変化の様子(空孔率 $f=$ $6.5 \%$ おび $0.82 \%$ )

$$
\boldsymbol{\Phi} \equiv\left[\begin{array}{ccc}
\Phi_{1} & 0 & 0 \\
0 & \Phi_{2} & 0 \\
0 & 0 & \Phi_{3}
\end{array}\right]
$$

; 村上一大野の損傷テンソル(8)

$$
\Phi_{i} \equiv\left(1-q_{2} \Omega_{i}\right)^{-1}
$$

$\Omega_{i} \equiv\{\pi /(2 \sqrt{3})\} \bar{a}^{3} / \bar{L}^{3}\left(L_{i} / a_{i}\right)$

; $i$ について総和規約を適用せず

$S_{i}^{\prime} \equiv S_{i}-\left(S_{1}+S_{2}+S_{3}\right) / 3$.

$E_{X} \equiv \exp (3 p / 2 Y)$

$p \equiv\left(\sigma_{1}+\sigma_{2}+\sigma_{3}\right) / 3$

$f \equiv 0.779\left(\bar{a}^{3} / \bar{L}^{3}\right)$

$\bar{L} \equiv\left(L_{1} L_{2} L_{3}\right)^{1 / 3}$

$\bar{a} \equiv\left(a_{1} a_{2} a_{3}\right)^{1 / 3}$

$R_{o} \equiv \Phi_{\mathrm{mld}} / \Phi_{\mathrm{sph}}$

$\Phi_{\mathrm{sph}} \equiv\left(1-q_{2} \Omega_{\mathrm{sph}}\right)^{-1}$

$=\left(1-k f^{2 / 3}\right)^{-1}$

$k \equiv q_{2}\{\pi /(2 \sqrt{3})\}(0.779)^{2 / 3}$

$\Omega_{\mathrm{sph}} \equiv\{\pi /(2 \sqrt{3})\}\left(\bar{a}^{2} / \bar{L}^{2}\right)$

$\Phi_{\text {mid }} \equiv\left(1-q_{2} \Omega_{\text {mid }}\right)^{-1}$

$\Omega_{\text {mid }} \equiv\{\pi /(2 \sqrt{3})\}\left(a_{\text {mid }}^{2} / \bar{L}^{2}\right)$

$a_{\text {mld }}$ ：だ円体の中間主軸半径

$Y$ : 母材の降伏応力

降伏関数 $(1)$ の様子が図 1 に示されているが, 純粋 静水圧の場合に対して, 空孔形状に基づく異方性の効 果が比較的大きく現れるように，前報(5)で提案された 降伏関数を改善したものである.

さて，構成式を導く過程で式 (1)の以後の取扱いが 容易となるように次のように書き変える.

$$
\begin{aligned}
& F\left(S_{i}, p, Y, f, \Phi_{\mathrm{mid}}\right)=(3 / 2) S_{i} S_{i} / Y^{2} \\
& \quad+q_{1}\left(f-k f^{5 / 3}\right) \Phi_{\mathrm{mid}} \cdot E_{X}-1=0 \quad \cdots
\end{aligned}
$$

塑性負荷に対する consistancy 条件を式(20)に適用し て次式を得る。

$$
\begin{aligned}
& \dot{F}=\left(\partial F / \partial S_{i}\right) \dot{S}_{i}+(\partial F / \partial \phi) \dot{p}+(\partial F / \partial Y) \dot{Y} \\
& +(\partial F / \partial f) \dot{f}+\left(\partial F / \partial \Phi_{\text {midd }}\right) \dot{\Phi}_{\text {mid }}
\end{aligned}
$$

ところで, 式 (20)を各変数に関して微分することによ り, 次の偏導関数を得る.

$$
\begin{aligned}
& \partial F / \partial S_{i}=3 S_{i}^{\prime} / Y^{2} \\
& \partial F / \partial p=q_{1}\left(f-k f^{5 / 3}\right) \Phi_{\text {mid }} \\
& \times(3 / 2 Y) E_{X} \\
& \partial F / \partial Y=-(2 / Y)\left\{S_{\text {eq }}^{2} / Y^{2}+(3 p / 4 Y)\right. \\
& \left.\times q_{1}\left(f-k f^{5 / 3}\right) \Phi_{\text {mid }} \cdot E_{X}\right\} \cdots \cdots \cdots \cdots \cdots \cdots \cdot(22 \cdot c) \\
& \partial F / \partial f=q_{1}\left\{1-(5 / 3) k f^{2 / 3}\right\} \Phi_{\text {mid }} \cdot E_{X} \cdots \cdots \cdots \cdot(22 \cdot \mathrm{d}) \\
& \partial F / \partial \Phi_{\text {mid }}=q_{1}\left(f-k f^{5 / 3}\right) \Phi_{\text {mid }} \cdot E_{X}
\end{aligned}
$$

さらに, 贯材の非圧縮性, 微視的および巨視的塑性仕 事量の等值性そして法線則が成立するものと仮定する 
とき，次式を得る.

$$
\begin{aligned}
& \dot{f}=(1-f) \delta_{i} \dot{\varepsilon}_{i} \\
& \dot{Y}=(2 / 3)\left\{E_{t} /(1-f)\right\} \sigma_{i} \dot{\varepsilon}_{i} / Y \\
& \dot{\varepsilon}_{i}=\Lambda\left(\partial F / \partial \sigma_{i}\right)
\end{aligned}
$$

ここで,

$\delta_{i}$ : 単位テンソル

$E_{t}$ : 母材の単軸引張応力ひずみ曲線の接線係数

$\Lambda$ :スカラ

$$
\begin{aligned}
& \partial F / \partial \sigma_{i}=3\left(S^{\prime} \Phi\right)_{i} / Y^{2} \\
& \quad+q_{1} f_{1} \Phi_{\text {mld }} E_{X} \delta_{i} /(2 Y)
\end{aligned}
$$

$(A B)_{i}: A_{i} B_{i}$ (総和規約を適用せず)

さて, 構成式の誘導をさらに進めるためには, 損傷テ ンソル $\Phi_{i}$, すなわち空孔の成長に関する発展方程式 が必要となるが,これについては Rice と Traceyに よる研究(6) に基づき, 空孔とその周辺のひずみ場の偏 差成分間に次のような関係を仮定して解決できる。

$$
\dot{\boldsymbol{\varepsilon}}_{\text {vold }}^{\prime}=\dot{\boldsymbol{\varepsilon}}_{\text {matrix }}^{\prime}
$$

Rice と Tracey は無限領域母材中に置かれた空孔 のひずみを議論する際に, 空孔の体積ひずみ速度と空 孔の遠方に存在する非圧縮性ひずみ速度場の和として 空孔内のひずみ場が表現されるとしており，式(26)は こうした Rice-Tracey の仮説を有限領域母材問題へ 拡張した関係のある特殊形と解釈できる(付録 1 参 照)。さて，発展式について，まず，式（7）を時間に関 し微分することにより，i=1に対して次式を得る。

$$
\dot{\Omega}_{1}=\Omega_{1}\left(\dot{a}_{k} / a_{k}-\delta_{k} \dot{\varepsilon}_{k}-\dot{a}_{1} / a_{1}+\dot{\varepsilon}_{1}\right)
$$

これに式(23)，(26)と $\dot{f}=f\left\{\left(\dot{a}_{k} / a_{k}\right)-\delta_{k} \dot{\varepsilon}_{k}\right\}$ を代入し $\tau, \Omega_{1}$ に対する発展式を得る。

$$
\dot{\Omega}_{1}=\sum_{1} \delta_{k} \dot{\varepsilon}_{k}
$$
ただし，

$$
\Sigma_{1}=(2 / 3) \Omega_{1}\left(f^{-1}-1\right)
$$

同様な関係が指標 $i=2,3$ に対して得られる.式 (28) は Nagaki らによって仮定された損傷テンソル発展 式(9) と一致していることは興味深い.

式(22)〜 (25)を式(20)に代入して得られた $\Lambda$ を式

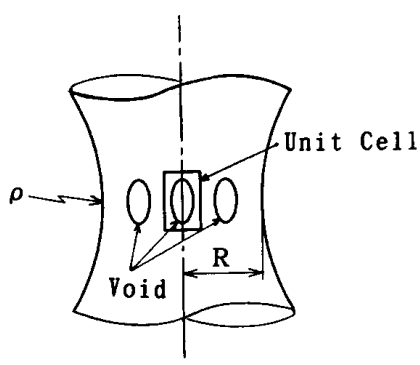

図 2 丸棒くびれ部の中央部における空孔と延性破壊解析 のための単位セル
（25）に用いることにより，最終的に次のような降伏条 件式（1）に基づく直交異方性構成式を得ることができ る.

$$
\dot{\varepsilon}_{i}=(1 / H) m_{i} m_{k} \dot{\sigma}_{k}
$$

ただし

$$
\begin{aligned}
& m_{i}=(3 / 2 Y)\left(S^{\prime} \Phi\right)_{i}+\alpha \delta_{i} \\
& \alpha=\left(q_{1} / 4\right)\left(f-k f^{5 / 3}\right) \Phi_{\text {mid }} \cdot E_{X} \\
& H=\left\{h_{M} /(1-f)\right\}\{\omega+\alpha(3 p / Y)\}^{2} \\
& -3 Y\left\{S_{i}^{\prime} \Phi_{i} / 2 Y+\alpha\right\}\left\{(3 / 2) Y^{-2}\right. \\
& \left.* S_{j}^{\prime}(\sigma \Sigma)_{j}+(1-f) \gamma+2 \alpha\right\} \\
& \omega=\left(S_{\text {eq }} / Y\right)^{2} \\
& \gamma=\left(q_{1} / 2\right)\left\{1-(5 / 3) k f^{2 / 3}\right\} \Phi_{\text {mid }} \cdot E_{X} \\
& h_{M}=2 E_{t} / 3
\end{aligned}
$$

\section{3. 延性破壊解析}

延性破壊解析を行うためには，臨界条件としての不 安定開始条件を明確に定義しなければならないが，こ れに対し本研究では Thomasonの理論に基づいて進 めるものとする.まず Thomason の平面ひずみモデル における長方形空孔を丸棒のくびれ問題に対し妥当な ように軸対称状態へと拡張することを考える。そこで, 一様な一軸引張変形の後にくびれ変形が生じ, くびれ 部の中央において，図 2 に示すように空孔が隣接して いるものと仮定しょう。ささらに，その隣接する空孔間 のリガメント部に変形が集中する過程の解析を簡単に するために，図中に示すようにくびれ部の中央におい て軸対称単位セルが抽出できるものとしよう.

さらに, 図 2 で抽出された単位セル中のだ円体空孔 を, 長さ $a$ と半径 $b$ を持つ円筒状空孔で置き換え, 図 3 に示すように母材領域を三つの領域 I, II, IIIに分 割する単位セルモデルとして仮定する。ただし，図中 のすべての寸法は単位セルの半径で無次元化された量 である.このモデルの拘束係数を得るために，剛塑性

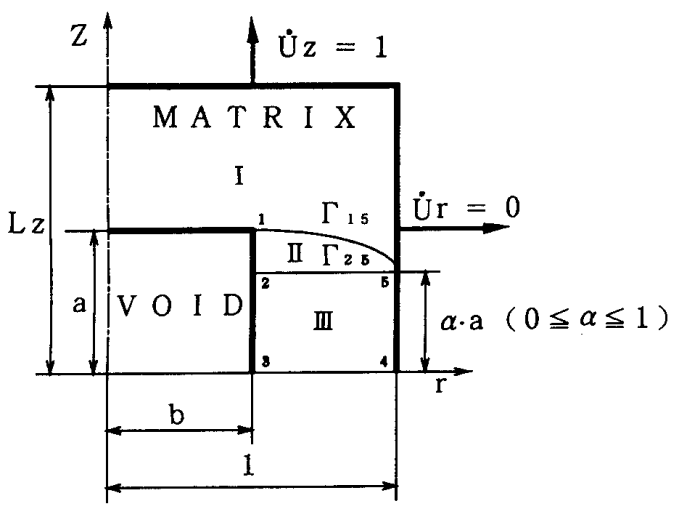

図 3 上界定理を適用するために導入された軸対称単位セ ルと近似速度場領域の分割様子 
体に対する上界定理を適用する。同様な解析は過去に 円筒の圧縮問題について Kudo ${ }^{(10)}$, Avitzur ${ }^{(11)}$ そして 小林(12)によりなされているが，ここでは境界条件を 適切に満足する速度場が次に示すように仮定された。

領域 Iにおいて(剛体場)：

$\dot{u}_{r}=0, \quad \dot{u}_{z}=1$

領域Iにたいて：

$\dot{u}_{r}=\left(1-b^{2}\right) /(2 a r), \quad \dot{u}_{z}=\alpha$

領域IIIにおいて：

$$
\dot{u}_{r}=\left(1-r^{2}\right) /(2 a r), \quad \dot{u}_{z}=z / a
$$

不連続曲線 $\Gamma_{15}$ は曲線に浻う垂直速度成分の連続条 件より得られ，その結果は以下のとおりである。

$$
Z_{15}=a(1-\alpha)\left(1-r^{2}\right) /\left(1-b^{2}\right)+\alpha a
$$

各領域に対する散逸内部仕事率は仮定された速度場
(36)〜(38)を用いて次のように得られる.

領域IIに対して：

$$
\begin{aligned}
& \dot{W}_{125}=\iint Y \vec{\varepsilon} 2 \pi r d r d z \\
& \quad=\{\pi(1-\alpha) / \sqrt{3}\} Y\left[\ln b^{-2}-\left(1-b^{2}\right)\right] \cdots(40) \\
& こ こ て ゙, \\
& \bar{\varepsilon}=\left(1-b^{-2}\right) /\left(\sqrt{3} a r^{2}\right)
\end{aligned}
$$

領域IIIに対して：

$$
\begin{aligned}
& \dot{W}_{2345}=\iint Y \vec{\varepsilon} 2 \pi r d r d z \\
& =(\pi \alpha / \sqrt{3}) Y\left[2-\left(3 b^{4}+1\right)^{1 / 2}\right. \\
& \left.\quad+\ln b^{2}-\ln \left\{\left(3 b^{4}+1\right)^{1 / 2}-1\right\}\right] \\
& \text { ここで, } \\
& \vec{\varepsilon}=\left(3+r^{-4}\right)^{1 / 2} /(\sqrt{3} a)
\end{aligned}
$$

不連続面 $\Gamma_{15}$ に対して：

$$
\begin{aligned}
& \dot{W}_{\Gamma 15}=(1 / \sqrt{3}) \int Y|\Delta \dot{u}| d S=(2 \pi / \sqrt{3}) Y \int r\left|\Delta \dot{u}_{15}\right| d r / \cos \theta=(\pi Y / \sqrt{3})\left[(4 / 3)\left(1+b+b^{2}\right)\right. \\
& \left.*(1-\alpha)^{2} a /(1+b)+\left(1-b^{2}\right)(1+b) / a\right]
\end{aligned}
$$

ここで, $\left|\Delta \dot{u}_{15}\right|: \Gamma_{15}$ に沿う接線速度成分の不連続量.

$$
\left|\Delta \dot{u}_{15}\right|=(1-\alpha) \sin \theta, \quad \tan \theta=-a(1-\alpha) r /\left(1-b^{2}\right)
$$

不連続面 $\Gamma_{25}$ に対して：

$$
\dot{W}_{\Gamma 25}=(1 / \sqrt{3}) \int Y\left|\Delta \dot{u}_{25}\right| 2 \pi r d r=(\pi Y / \sqrt{3})\left[(1-b)\left(1+b-2 b^{2}\right) /(3 a)\right]
$$

ここで, $\left|\Delta \dot{u}_{25}\right|: \Gamma_{25}$ に沿う接線速度成分の不連続量.

$$
\left|\Delta \dot{u}_{25}\right|=\left(r^{2}-b^{2}\right) /(2 a r)
$$

結局, 全内部散逸仕事率は次式となる.

$$
\begin{aligned}
& \dot{E}_{\mathrm{Int}}=\dot{W}_{125}+\dot{W}_{2345}+\dot{W}_{r 15}+\dot{W}_{r 25}=(\pi Y / \sqrt{3})\left[(1-\alpha)\left\{\ln b^{-2}-\left(1-b^{2}\right)\right\}\right. \\
& \quad+\alpha\left[2-\left(3 b^{4}+1\right)^{1 / 2}+\ln b^{2}-\ln \left\{\left(3 b^{4}+1\right)^{1 / 2}-1\right\}\right]+\left\{(4 / 3)\left(1+b+b^{2}\right)(1-\alpha)^{2} a\right. \\
& \left.\left.\quad \div(1+b)+\left(1-b^{2}\right)(1-b) / a\right\}+(1-b)\left(1+b-b^{2}\right) /(3 a)\right] \ldots \ldots \ldots \ldots \ldots \ldots \ldots \ldots \ldots \ldots \ldots \ldots \ldots \ldots \ldots \ldots \ldots \ldots \ldots . . .
\end{aligned}
$$

$z=a$ に浻うリガメント部における平均軸応力を $P_{\mathrm{ave}}$ と記すとき, 単位軸方向速度に対して外部散逸仕事率は次の ようになる。

$$
\dot{E}_{\mathrm{ext}}=\pi\left(1-b^{2}\right) * 1 * P_{\mathrm{ave}}
$$

$\dot{E}_{\mathrm{ext}}$ と $\dot{E}_{\mathrm{int}}$ が等しいという条件から拘束係数 $C_{n}\left(=P_{\mathrm{ave}} / Y\right)$ に関する次の結果を得る。

$$
\begin{aligned}
& C_{n}=(\pi / \sqrt{3})\left[(1-\alpha)\left\{\ln b^{-2}-\left(1-b^{2}\right) /\left(1-b^{2}\right)-1\right\}+\left\{\alpha /\left(1-b^{2}\right)\right\}\right. \\
& *\left[2-\left(3 b^{4}+1\right)^{1 / 2}+\ln b^{2}-\ln \left\{\left(3 b^{4}+1\right)^{1 / 2}-1\right\}\right]+\left[(4 / 3)\left(1+b+b^{2}\right)(1-\alpha)^{2} a\right. \\
& \left.\div\left\{(1+b)\left(1-b^{2}\right)\right\}+(1-b) / a\right]+\left(1+b-b^{2}\right) /\{(3 a(1+b)\}]
\end{aligned}
$$

$\alpha$ をパラメータとして式 $(36) \sim(38)$ で仮定された速度場の中で実際に実現され得る場の近似解は $C_{n}$ を最小とす るものである.ところで, 式(46) は $\alpha$ に関する二次方程式で, $\alpha^{2}$ の係数は正であるから, したがって拘束係数を最 小化する $\alpha$ を次のように唯一に決定することができる.

$$
\alpha_{s}=1-3(1+b)\left[3-b^{2}-\left(3 b^{4}+1\right)^{1 / 2}+\ln b^{4}-\ln \left\{\left(3 b^{4}+1\right)^{1 / 2}-1\right\}\right] /\left\{8 a\left(1+b+b^{2}\right)\right\}
$$

得られた $\alpha_{s}$ を式(46)に代入して, 内部くびれを引き起こす速度場が実現するに必要な最小拘束係数を求めるこ とができる.図 4 はここで得られた軸対称問題に対する拘束係数およびThomason による平面ひずみ問題に対する 拘束係数の分布を示す。この結果より，拘束係数がリガメント部の形状に大きく依存するものであることがわかる が, 軸対称の場合の拘束係数の値は平面ひずみの場合と異なり 1 に接近しない. 


\section{4. 内部くびれ開始規準}

丸棒に生じたくびれ変形はその中心部において静水 圧成分をもたらすが, Bridgman"(7)はくびれ断面にお いてひずみが一様に分布すると仮定し，軸方向応力 $\sigma_{z}$ と半径方向応力 $\sigma_{r}$ によりびれ部の応力状態が表現 できるという結論を得た。それによると，本研究にお いて関心のもたれているくびれ部の中央部近傍の応力 状態は次のように表せる.

$$
\begin{aligned}
& \sigma_{r} / Y=\ln \{1+0.5(R / \rho)\} \cdots \cdots \\
& \sigma_{z} / Y=1+\ln \{1+0.5(R / \rho)\} \cdots
\end{aligned}
$$

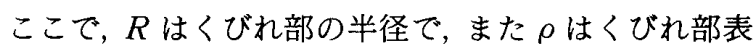
面の曲率半径である。

Bridgman は $R / \rho$ とくびれ部における軸方向巨視 的ひずみ $\int d \varepsilon_{z}$ に対し次の近似式の成立を報告してい る.

$$
R / \rho=\left(\int d \varepsilon_{z}-\varepsilon_{\text {neck }}\right)^{1 / 2}
$$

ここで， $\varepsilon_{\text {neck }}$ はくびれ開始時点の軸ひずみである.

さて, 図 3 のモデルの軸方向力の釣合いを考察する ことにより，Thomasonの規準の直接的拡張である次 の不等式を導入することができる.

$$
S * \sigma_{z}>P_{\text {ave }}\left(S-S_{v}\right)
$$

ここで, $S$ と $S_{v}$ は単位セルの公称および空孔の軸方 向断面積である.

式(51)に式(49)を代入した後, 損傷テンソルと拘束 係数を導入し，軸対称問題に対する内部くびれ条件を 次のように得る。

$$
1+\ln \{1+0.5(R / \rho)\}>C_{n}\left(1-\Omega_{z}\right)
$$

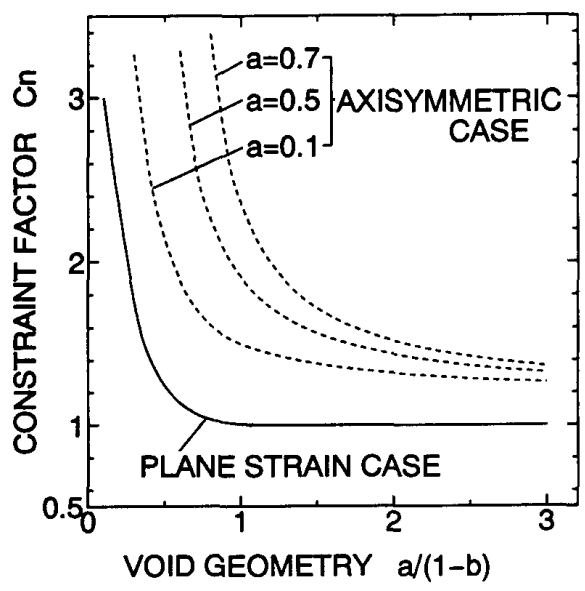

図 4 平面ひずみ場(Thomason の仮定)および軸対称ひず み場に対する拘束係数 $C_{n}$ と空孔形状との関係

\section{5. 解析結果と Edelson らの 実験結果との比較}

延性破壊解析モデルより得られたいくつかの結果が 図 5 に示されている。これらの結果と比較されるべき 実験值として, Edelson と Baldwin の研究(4)で得ら れた種々の焼結材に対する延性破壊点が図中に○印で 示されている. 本研究で得られた理論曲線が実験值曲 線と比較的よく一致していることがわかる.

理論計算においては，すべての材料は線形加工硬化 の渆塑性体と仮定され解析が進められたが, 付録 2 中 の解析手続きに示されるように, 加工硬化係数自体の 值は本理論の結果に関係しないものとなっている。こ れは, Edelson と Baldwinの実験が種々の異なる材 料に対してなされたにもかかわらず，材料に依存せず ある限られた範囲に分布する傾向を示していることと 照らし合わせて考えるとき興味深いものがある．しか しながら, 材料の違いはくびれ変形を開始するひずみ $\varepsilon_{\text {neck }}$ の值に基本的に影響するものであるから，異な る值を用いて計算を行いその影響の程度を調べた，図 5 に示されているようにその結果は初期空孔率が小さ い場合, 最終的破断ひずみに $\varepsilon_{\text {neck }}$ の值はそれほど大 きく影響しない傾向を示しているが，初期空孔率が 0.1 よりさい領域では, $\varepsilon_{\text {neck }}$ の值の違いによる差が かなり大きなものとなっている。これは，次のような ことが原因として考えられる。まず， $\varepsilon_{\text {neck }}=0.3$ とした ときは，そのひずみ值に至るまで局所くびれが生ぜず に一様な伸び変形となるので, その間静水圧応力が十

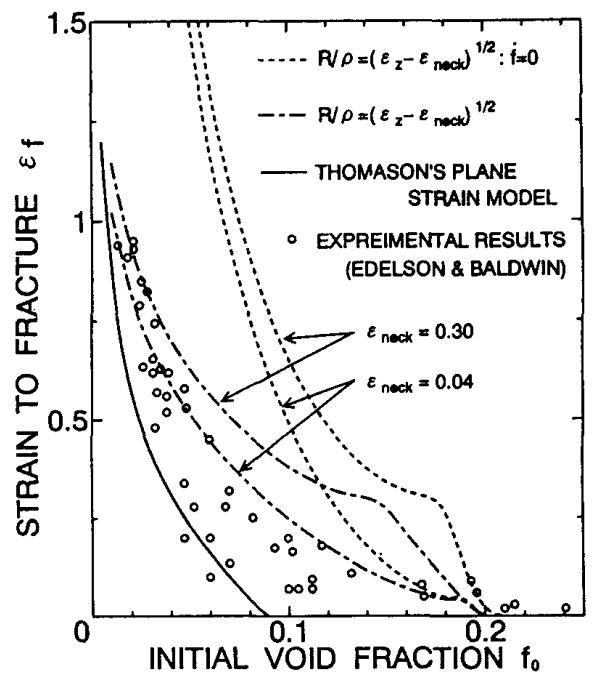

図 5 本研究で得られた理論延性破壊曲線と Edelson と Baldwin の焼結材に対する実験結果との比較(図中 破線は空孔成長に対する静水圧効果を無視した場合 の結果を示す) 
分に発達しないことになる。これに対応して，空孔も 半径方向に十分には成長せず，初期空孔率全域におい て延性破壊ひずみ值が大きくなるのである，そこで， さらに初期空孔率が 0.1 以上の場合, 空孔径は初期に おいて既に十分に大きく，したがって，くびれ開始後， 延性破壊ひずみ值までいくらも変形しないうちに臨界 条件に到達してしまうので全ひずみ值に占める $\varepsilon_{\text {neck }}$ の割合が結果的に大きなものとなってしまうのであ る.

さらに同図中に, Thomason らの平面ひずみモデル による結果が示されている。 また, Thomasonの設け た仮定の一つである，変形中一貫して一定空孔率であ るとした場合の本解析モデルからの結果も示されてい る. それによると，一定空孔率の仮定下で得られた結 果は, 非現実的なかなり大きな限界值を与える結果と なりこれは直感的に当然の帰結であり,ひいては解 析法の妥当性を裏付けるものである.したがって， McClintock やその他の研究者らの報告にあるように， この種の問題に対しては負(引張り)の静水圧力が空孔 の成長を加速する点で重大な役割を演ずるものである ことがわかる.

\section{6. まとめ}

本研究において, 微視的観点に基づくThomason の延性破壊理論の拡張が多孔質材異方性構成式論を導 入してなされた。昖張された解析は，いくつかの近似 と簡単な仮定の基に展開されたものであるにもかかわ らず，延性破壊に対する静水圧の影響を相応に評価で きるものであり，焼結材に対する実験結果との比較も 定性的にはよく一致しており，延性破壊に関する基本 的メカニズムをおおむねよく説明するものと思われ る.

実験と理論の明確な差をもたらす主たる要因として は, Rice らの仮定に基づく損傷变数の発展式の導入 や Bridgman の応力評価式の多孔質材に対する導入 がある. 損傷変数の発展式は空孔の成長に直接関係し， そして Bridgmanの仮定は内部くびれ規準に直接関 係するものであるから，特にこれらの二つの要因は, それぞれ注意深く考察されるべきである. 今後, Rice と Tracey の仮定自体の検討やそこで導入されている 係数(付録 1 中の $E$ ) のひずみ径路依存性等について より詳細に調べていく必要があろう.また, Bridgman の公式は非多孔質材の応力分布を推定するために得ら れたものであるから，公式の多孔質材への直接的適用 については基本的に問題があり，多孔質材に対し妥当 な評価式の導入の检討が不可欠である。
終わりに，本研究を遂行するにあたり，池谷科学技 術振興財団 (平成 5 年) 上りの援助に対し深く感謝の意 を表す。

\section{付 録 1}

式(26)が Rice らの仮定より得られる関係の㹡張形 であることが以下のように示される。

まず, 式(26)は $i=1$ に対して次のようになる.

$$
\dot{a}_{1} / a_{1}-(1 / 3) \dot{a}_{k} / a_{k}=\dot{\varepsilon}_{1}-(1 / 3) \delta_{k} \dot{\varepsilon}_{k} \cdots \cdots \cdots \text { (53) }
$$

もし，無限領域母材中の一つの空孔を考元るものとす ると，母材の非圧縮性により $\delta_{K} \varepsilon_{K}$ は零に漸近するか ら式(53)は次のようになる.

$$
\dot{a}_{1} / a_{1}=\dot{\varepsilon}_{1}+(1 / 3) \dot{a}_{k} / a_{k}
$$

ところで, Riceらの速度場に対する仮定より次の関 係が得られる。

$$
\dot{\varepsilon}_{\text {vold }}^{\prime}=(1+E) \dot{\varepsilon}_{\text {matrix }}
$$

ここで, $E$ は非圧縮速度場の空孔变形に及沽寸影響 の程度を評価する係数である。

式(55)に扔いて一軸引張応力下の係数 $E$ に対して Rice らは $E=1$ なる結果を得たが, Worswick らは変 形が大きくなるにつれて $E=0$ に漸近することを示し ている(12). 本研究で導入された式(54) は $E=0$ と置い た関係にほかならない。

\section{付 録 2}

\section{[解析手続き]}

(1)初期条件の設定：初期状態に対して, 球状空孔の 等方分布を仮定し, 初期空孔率 $f_{0}$ を与光, 初期単位七 ルの大きさを無次元寸法を導入して $L_{0}=1$ とする.

(2)増分 $\varepsilon_{z}$ を与光, $\varepsilon_{z}(t+d t)\left\{=\varepsilon_{z}(t)+\dot{\varepsilon}_{z}\right\}$ を求め る. 式(48) (50)に $\varepsilon_{z}(t+d t)$ を用いて, $\sigma_{z}(t+d t)$ と $\sigma_{r}(t+d t)$ を求める. ただし, $\varepsilon_{\text {neck }}>\varepsilon_{z}(t+d t)$ の場合 は $\rho=\infty$ として応力を求める.

(3)增分ひずみ比 $R_{v}\left\{=\dot{\varepsilon}_{v} / \dot{\varepsilon}_{z}\right\}$ に式(29)を代入して 得られた次式から求める.

$$
R_{v}=1+2 *\left(m_{r} / m_{z}\right)
$$

この段階で構成式中に含まれていた加工硬化係数が 消去されていることに着目すべきで, その結果として 硬化係数は本解析に影響しないことになっている.

(4) $\dot{\varepsilon}_{v}\left(=R_{v} * \dot{\varepsilon}_{z}\right)$ を用いて, 次の増分量を計算する.

$$
\begin{aligned}
& \dot{\Omega}_{z}=(2 / 3) \Omega_{z}\left(f^{-1}-1\right) \dot{\varepsilon}_{v} \\
& \dot{\Omega}_{r}=(2 / 3) \Omega_{r}\left(f^{-1}-1\right) \dot{\varepsilon}_{v} \\
& \dot{a}_{z}=\left\{1+R_{v}(1-f) /(3 f)\right\} \dot{\varepsilon}_{z} \\
& \dot{a}_{r}=\left\{0.5+\left(R_{v}-1\right)+R_{v}(1-f) /(3 f)\right\} \dot{\varepsilon}_{z}
\end{aligned}
$$

$\dot{f}=(1-f) R_{v} \dot{\varepsilon}_{z}$ 
(5) $a_{z}, a_{r}, L_{z}, L_{r}, \Omega_{z}, \Omega_{r}$ と $f$ を簡単な数值積分に より $t+d t$ 時刻量へアプデイトする。

(6) $a_{z}, a_{r}$ と $L_{r}$ を用いて, 式(46)と式(47)より拘束 係数 $C_{n}$ を求める.

(7)アプデイトされた $\Omega_{z}$ と $\Omega_{r}$ と $C_{n}$ を内部くびれ 規準式 (52)に代入する。もし，規準が満足されたなら ば, 臨界ひずみとして $\varepsilon_{z}(t+d t)$ を出力する．満足さ れない場合は, (2)へ戻る。

\section{文献}

(1) Thomason, P. F., J. Inst. Met., 96 (1968), 360.

(2) McLintock, F. A., Trans. ASME, J. Appl. Mech., 35-2 (1968), 363.

(3) Berg, C. A., Proc. 4th US Natl. Congr. Appl. Mech., 2
(1962), 885.

(4) Edelson, B. I. and Baldwin, W. M. Jr., Trans. Am. Soc. Met., 55(1962), 231.

(5) Goya, M., Nagaki, S. and Sowerby, R., JSME Int. J., Ser. I, 35-3(1992), 310.

(6) Rice, J. R. and Tracey, D. M., J. Mech. Phys. Solids, 17 (1969), 201.

(7) Bridgman, P. W., Trans. Am. Soc. Met., 32(1943), 553.

（8）村上・大野, 機論, 46-409, A(1980), 940.

(9) Nagaki, S., Goya, M. and Sowerby, R., Int. J. Plasticity, 9(1993), 199.

(10) Kudo, H., Int. J. Mech. Sci., 2(1960), 102.

(11) Avitzur, B., Trans. ASME, J. Eng. Ind., 95(1973), 827.

(12) Kobayashi, S., loc. cit., 86(1964), 122.

(13) Worswick, M. J. and Pick, R. J., J. Mech. Phys. Solids, 38-5(1990), 601. 